\title{
Adding Nutrients to Enhance the Growth of Endangered Sockeye Salmon: Trophic Transfer in an Oligotrophic Lake
}

\author{
Phaedra Budy, ' Chris Luecke, and Wayne A. Wurtsbaugh \\ Department of Fisheries and Wildlife and Ecology Center \\ Utah State University, Logan, Utah 84322-5255, USA
}

\begin{abstract}
Snake River sockeye salmon Oncorhynchus nerka, listed under U.S. law as endangered in 1991 in response to a decline in anadromous adult numbers, spend their first 1-2 years in Redfish Lake, Idaho, before migrating to the sea. To determine how nutrient enhancement might influence phytoplankton, zooplankton, and fish production, we performed fertilization experiments in large enclosures in this oligotrophic lake using juvenile kokanee (lacustrine $O$. nerka) as analogues for endangered sockeye salmon. Fertilization of the metalimnion substantially increased chlorophyll $a(150 \%)$, phytoplankton biovolume (75\%), primary productivity (250\%), and zooplankton biomass (200\%), and moderately increased fish growth (12\%) over our control enclosures. Community composition of phytoplankton and zooplankton changed little, and water transparency declined less than $15 \%$ compared with controls. Thus, we concluded that metalimnetic fertilization could maintain the aesthetic value of these lakes while increasing zooplankton food resources for juvenile salmon. Our results suggest that whole-lake fertilization would aid in the recovery of Snake River sockeye salmon.
\end{abstract}

The importance of food resources in controlling the biomass of organisms in a given trophic level has been a dominant theme in community ecology for several decades. These bottom-up effects have been predicted from theory (Fretwell 1977; Oksanen 1988; Liebold 1989; Power 1992), described from empirical relationships (McQueen et al. 1986), and tested with whole ecosystem experiments (McNaughton 1977; Langeland 1982; Peterson et al. 1993). Adding nutrients to enhance ecosystem productivity has been practiced for thousands of years and forms the foundation of agricultural and aquaculture practices. In fisheries sciences, Nelson and Edmondson (1955) demonstrated 40 years ago that lake fertilization increases production of commercially exploited stocks; lake fertilization is now commonly used in Alaska and Canada to increase growth and production of juvenile sockeye salmon Oncorhynchus nerka (Stockner 1981, 1987; Stockner and Hyatt 1984; Kyle 1994).

Although bottom-up effects from nutrients are measurable, our ability as ecosystem managers to predict the magnitude of these effects is weak (Power 1992). Much current ecological debate centers on determining when bottom-up effects prevail over top-down effects in defining ecosystem function (Carpenter and Kitchell 1988, 1992;

\footnotetext{
${ }^{1}$ Present address of corresponding author: U.S. Fish and Wildlife Service, Columbia River Fisheries Program Office, Suite I, Vancouver, Washington 98665, USA; phaedra_budy@mail.fws.gov
}

DeMelo et al. 1992; Matson and Hunter 1992). Primary production has been enhanced in many studies in which nutrients have been added to aquatic systems (Liebold 1989). In some cases, however, intense selective predation on primary consumers can weaken or obliterate the effects of nutrient additions, resulting in a strong top-down control of ecosystem function (Carpenter and Kitchell 1993). Omnivory or diet switching by consumers also can reduce trophic transfer resulting in "middle-out" effects (Polis et al. 1989; DeVries and Stein 1992). Finally, reproductive limitation of key species can uncouple the trophic link between primary producers and consumers (Koenings and Burkett 1987).

In spite of the well-known effects of nutrient additions, we know of no instance in which ecosystem fertilization has been used as a management tool to assist with the recovery of endangered populations. In this paper, we examine the potential for using lake fertilization to enhance growth and survival of endangered sockeye salmon in Redfish Lake, Idaho. Snake River sockeye salmon would probably benefit from an increase in juvenile size in making the long migration from the freshwater nursery lakes to the Pacific Ocean $(>1,400 \mathrm{~km})$, a journey that formerly took less than $10 \mathrm{~d}$ but now can take over 2 months due to delays associated with dam passage on the Columbia and Snake rivers. Similarly, predation on juvenile salmonids is thought to be highly size-specific, with small increases in growth rate translating to large differences in survival (Luecke et al. 
1990; Marschall and Crowder 1995). Thus a larger-size juvenile sockeye might be better able to avoid piscivorous fish waiting in the reservoirs of these dams (Poe et al. 1991; Rieman et al. 1991; Vigg et al. 1991).

We conducted a fertilization experiment in large, impermeable enclosures to compare patterns of trophic transfer in control and nutrient addition treatments. We compared nutrient concentration, chlorophyll $a$, phytoplankton biomass and composition, primary production, zooplankton biomass and composition, and fish growth between treatments. We used juvenile kokanee (a conspecific but nonendangered population of $O$. nerka) as a surrogate for sockeye salmon in this experiment and assessed the degree to which nutrient additions were transferred to increases in biomass of organisms at higher trophic levels. Kokanee are the same species as sockeye salmon but remain in the lake for the duration of their life cycle. The anadromous sockeye salmon migrate to the Pacific Ocean after 1-2 years in the nursery lake. Sockeye salmon and kokanee in Redfish Lake are monophyletic and are genetically more similar to each other than to any similar forms in another geographic area (Winans et al. 1996). In addition to their monophyletic origin, juvenile kokanee and sockeye salmon experience the same ecological conditions for the first year of their life, which makes these kokanee ideal surrogates for evaluating the factors that determine growth of endangered sockeye salmon in the freshwater nursery lake. Endangered sockeye salmon were not available for this experiment due to low numbers of broodstock progeny.

\section{Study Site and History}

Redfish Lake, one of five historical rearing lakes of endangered Snake River sockeye salmon, is located in the Sawtooth Range of central Idaho. These sockeye salmon migrate over $1,400 \mathrm{~km}$ from the Pacific Ocean up the Columbia, Snake and Salmon rivers to spawn in Redfish Lake. The juveniles spend 1-2 years in the nursery lake before migrating back to the Pacific Ocean. Several thousand adults once returned to the lake, but when returns diminished to less than 10 per year, the Snake River strain of Sockeye Salmon was listed under U.S. law as an endangered species (Bevan et al. 1994). The few adults that have returned in recent years were captured, and their progeny are being raised as part of an emergency broodstock program for future stocking back into the nursery lakes.
Redfish Lake, the only nursery lake that endangered sockeye have returned to in recent times, is a small, glacially formed lake situated at $1,996 \mathrm{~m}$ elevation. The lake is $6.15 \mathrm{~km}^{2}, 91 \mathrm{~m}$ in maximum depth, $44 \mathrm{~m}$ in mean depth, and has a $108-\mathrm{km}^{2}$ watershed. In addition to Redfish Lake, four other nearby lakes historically supported sockeye salmon. All of the lakes are ultraoligotrophic, with mean summer chlorophyll values ranging from 0.5 to $1.0 \mu \mathrm{g} / \mathrm{L}$, mean summer Secchi depth transparencies ranging from 8 to $16 \mathrm{~m}$, and total crustacean zooplankton biomass ranging from 1 to $120 \mu \mathrm{g} / \mathrm{L}$ (Budy et al. 1995). See Budy et al. (1995) for detailed limnological information on Redfish Lake and the other four historical sockeye lakes.

\section{Methods}

Fertilization experiments were performed in nine large enclosures called limnocorrals $\left(350 \mathrm{~m}^{3}\right.$, $5 \mathrm{~m}$ in diameter, and $17 \mathrm{~m}$ deep), made of impermeable, polyethylene plastic. The limnocorrals were slowly dropped from the surface with the bottom open, allowing each to fill with lake water during $24 \mathrm{~h}$. Thus, initial conditions within each limnocorral were similar to the lake. When the limnocorral was filled, scuba divers closed the bottom section.

Three treatments were established: control (C), fish (F), and nutrients and fish (NF), each with three replicates. Treatment $\mathrm{C}$ received neither fish nor nutrients, and treatment $\mathrm{F}$ was stocked with juvenile kokanee. Treatment NF received regular additions of nitrogen and phosphorus fertilizer and was also stocked with juvenile kokanee. In a previous experiment in which we added nutrients and fish to limnocorrals at the same time, we observed large increases in chlorophyll $a$ but no subsequent increase in zooplankton biomass, probably because of intense planktivory by the fish (Budy et al. 1994). Therefore, in this experiment, we added nutrients to the limnocorrals for 2 months before the fish were added. This treatment allowed the phytoplankton and zooplankton communities to respond to the fertilizer addition and overcome the time lag between fertilizer addition and zooplankton production before the planktivorous kokanee were added. Thus, the experiment was conducted in two parts. In part 1 (13 June 1994-12 August 1994), nutrients were added to three of nine limnocorrals (NF), and in part 2 (13 August 1994-11 September 1994), nutrient additions continued and fish were added to three fertilized (NF) and three unfertilized limnocorrals $(F)$.

During the first 9 weeks of the experiment (part 
1), we compared the six limnocorrals that received no nutrients $(\mathrm{C}$ and $\mathrm{F})$ to the three nutrient addition limnocorrals (NF). In the NF treatment, nitrogen and phosphorus fertilizer was added every $10 \mathrm{~d}$ to the metalimnion of each limnocorral. We chose metalimnetic fertilization because Redfish Lake has a pronounced deep chlorophyll maximum in that zone and because deep fertilizations can effectively stimulate plankton production while minimizing decreases in water transparency (LeBrasseur et al. 1978; Gross et al. 1994). Nutrients were added at $11 \mathrm{~m}$ during part 1 of the experiment and at $12 \mathrm{~m}$ in part 2 of the experiment because the thermocline moved deeper.

Nitrogen and phosphorus were added to the metalimnion (11-12 m) of the NF treatment in the form of $\left(\mathrm{NH}_{4}\right)_{2} \mathrm{HPO}_{4}$ and $\mathrm{NH}_{3} \mathrm{NO}_{3}$ every $10 \mathrm{~d}$ at a 30:1 ratio (total nitrogen:total phosphorus, by mass; 13.5:1 molar ratio). The addition of $5 \mu \mathrm{g}$ phosphorus $/ \mathrm{L}$ and $150 \mu \mathrm{g}$ nitrogen $/ \mathrm{L}$ was designed to increase the total nutrient levels approximately $50 \%$ over levels in lake water. Similarly, the high total nitrogen:total phosphorus (TN:TP) ratio was used to reduce the likelihood of stimulating nitrogen-fixing cyanobacteria (Schindler 1977).

Juvenile kokanee were used as surrogates for the endangered sockeye salmon in these experiments. Kokanee were trapped shortly after emergence in May from Fishhook Creek, a Redfish Lake tributary, and retained in permeable mesh net-pens in Redfish Lake until addition to limnocorral fish treatments on 13 August 1994.

Limnocorrals were sampled immediately before fertilization, and every $10 \mathrm{~d}$ thereafter, for limnological variables including, chlorophyll $a$, zooplankton, Secchi depth transparency, temperature, and oxygen. Where applicable, data from samples taken in the lake during the experiment were provided for comparison. Water for the measurement of profiles of dissolved and total nutrients (total phosphorus, soluble reactive phosphorus (SRP), total Kjeldahl (TKN), and nitrate $\left(\mathrm{NO}_{3}\right)$ was collected four times during the experiment (13 June, 2 July, 2 August, and 31 August).

Secchi depth measurements were recorded in each limnocorral to estimate water clarity. Temperature and oxygen profiles were measured with a Hydrolab ${ }^{\circledR}$ meter in one randomly chosen limnocorral from each of the three treatments every $10 \mathrm{~d}$. Previous sampling indicated that little variation in temperature and oxygen occurred among limnocorrals in these types of experiments (Budy et al. 1994).

Water for chlorophyll- $a$ analysis and nutrients was collected with weighted polyethylene tubes for integrated depth samples and a 4-L Van Dorn bottle sampler for discrete depth samples. Epilimnetic water samples were taken with a 6-m tube, and whole limnocorral water column samples were taken with a 17 -m-long (0.02-m-diameter) tube every $10 \mathrm{~d}$. Discrete water samples were collected from the metalimnion ( 11 or $12 \mathrm{~m}$ ) every $10 \mathrm{~d}$ and from near the bottom of each limnocorral $(17 \mathrm{~m})$ on selected dates.

Water for nutrient analyses (TP, SRP, TKN, and $\mathrm{NO}_{3}+\mathrm{NO}_{2}$ ) was placed in polyethylene bottles previously rinsed with $0.1 \mathrm{~N} \mathrm{HCl}$ and then rinsed three times with aliquots of the sample water. Nutrient samples were frozen until analysis. Unfiltered water was used for TKN and TP analyses; samples analyzed for $\left(\mathrm{NO}_{3}+\mathrm{NO}_{2}\right)$ and SRP were filtered through $0.45-\mu \mathrm{m}$ membrane filters. The TP samples underwent a persulfate digestion and were then analyzed colorimetrically by the molybdateascorbic acid method (APHA et al. 1992). Nitrogen analyses were conducted by the University of California at Davis (Limnology Laboratory); a Kjeldahl digestion was used for TKN and the hydrazine method was used for $\mathrm{NO}_{3}+\mathrm{NO}_{2}$ (APHA et al. 1992). The TN was the sum of TKN and $\mathrm{NO}_{3}+\mathrm{NO}_{2}$. One randomly chosen sample for each nutrient analyzed, and for each sample date, was replicated and spiked, and standard solutions were used for quality assurance and quality control (APHA et al. 1992). Differences among mean nutrient concentrations for the two unfertilized treatments summed $(\mathrm{C}+\mathrm{F})$ versus the fertilized limnocorrals (NF) were statistically analyzed with analysis of variance (ANOVA) for each nutrient sampled (TP, SRP, TKN, and $\mathrm{NO}_{2}+\mathrm{NO}_{3}$ ).

Chlorophyll- $a$ measurements were used as a measure of phytoplankton standing crop. Two 50$\mathrm{mL}$ aliquots per sample were filtered through 0.45 $\mu \mathrm{m}$ cellulose acetate membrane filters. Filters were either temporarily frozen or placed directly into 6 $\mathrm{mL}$ of $100 \%$ methanol for chlorophyll pigment extraction in the dark for $24 \mathrm{~h}$. Extracts were then analyzed before and after acidification (HolmHansen and Rieman 1978) with a Turner model 111 fluorometer with corrections made for phaeopigments.

We preserved water for phytoplankton enumeration from the chlorophyll- $a$ and nutrient water samples described above. One to two limnocorrals per treatment per date were selected randomly for analysis to represent each treatment on that date. Phytoplankton samples were preserved with $\mathrm{Lu}$ gol's (iodine) solution, and a $100-\mathrm{mL}$ aliquot from 
each phytoplankton sample was filtered through a $0.45-\mu \mathrm{m}$ cellulose filter. The filters were cleared and permanently mounted (Crumpton 1987). Cells were counted in a minimum of 10 fields per slide at $400 \times$ magnification; the dimensions of a minimum of 10 individuals in each taxon were measured to calculate biovolume (Wetzel and Likens 1991). Phytoplankton were taxonomically classified as Cyanophyta (blue-green algae), Chlorophyta (green algae), Chrysophyta (Dinobryon sp. was the dominant chrysophyte), Bacillariophyta (diatoms), and Dinophyta (Peridinium sp. was the dominant dinophyte). Low numbers of replicate phytoplankton biovolume counts prevented statistical analysis of this variable.

Rates of in situ primary production (PPR) were also measured on two dates, 1 August 1994 (before fish) and 31 August 1994 (after fish), by using the ${ }^{14} \mathrm{C}$ technique (Wetzel and Likens 1991). Water from each of four depths $(0.5,6,11$ or 12 , and 17 $\mathrm{m})$ in all nine limnocorrals was incubated in three 25 -mL glass scintillation vials. Each vial was inoculated with $80 \mu \mathrm{L}$ of 25 -microcuries ${ }^{14} \mathrm{CHO}_{3} /$ $\mathrm{mL}$, and one vial at each depth was inoculated with $150 \mu \mathrm{L}$ of a saturated solution of photosynthetic inhibitor, diuron $\left(\mathrm{N}^{\prime}-(3,4,-\right.$ dichlorophenyl)-N, Ndimethyl-urea; DCMU) to measure nonphotosynthetic ${ }^{14} \mathrm{C}$ uptake. The vials were incubated at the appropriate depth in their respective limnocorrals for $4 \mathrm{~h}$ in clear acrylic plastic tubes. At the end of the incubation, the entire contents of each vial was filtered through a $0.45-\mu \mathrm{m}$ cellulose nitrate filter and rinsed with $0.01 \mathrm{~N} \mathrm{HCl}$. They were then air dried and subsequently counted by liquid scintillation spectrometry. Production rates were calculated by subtracting carbon uptake in the DCMU treatments from the light treatments. Dissolved inorganic carbon was estimated from $\mathrm{pH}$ and alkalinity measurements determined with the Gran procedure (Wetzel and Likens 1991). Differences in primary productivity among treatments were statistically analyzed with an ANOVA for the two dates sampled.

Periphyton accumulation on the walls of the limnocorrals was evaluated by suspending weighted 17 -m-long $\times 10$-cm-wide strips of the same polyethylene limnocorral material in the center of each corral. At every other sampling period ( $\sim 21 \mathrm{~d})$, we removed two $10-\mathrm{mm}$ squares from four depths $(1,6,11-12$, and $17 \mathrm{~m})$ on each strip. These squares were placed immediately in $6 \mathrm{~mL}$ of methanol, left to extract in the dark for $24 \mathrm{~h}$, and then analyzed fluorometrically for chlorophyll $a$ according to the methods described above.
Zooplankton were sampled from two depth strata, $10-0 \mathrm{~m}$ and $17-10 \mathrm{~m}$, every $10 \mathrm{~d}$ in each limnocorral. Two replicate samples were taken over each depth stratum with a closing $80-\mu \mathrm{m}$-mesh net that was $35 \mathrm{~cm}$ in diameter and $150 \mathrm{~cm}$ long and was equipped with an antireverse General Oceanics ${ }^{\circledR}$ flowmeter. Samples were immediately preserved in a $10 \%$ formalin-sucrose solution and subsequently counted and measured. The zooplankton taxa identified included four cladoceran species (Daphnia rosea, Bosmina longirostris, Holopedium gibberum, Polyphemus pediculus), one calanoid copepod (Epischura nevadensis), and at least two species of cyclopoid copepods. Dry biomass was calculated with length-mass regressions (McCauley 1984; Koenings et al. 1987), and densities were corrected for the volume sampled. To measure diel vertical migration of zooplankton in the limnocorrals, we sampled in the depth strata $(6-0,12-6,17-12)$ both during the day $(1200$ hours) and then again $12 \mathrm{~h}$ later at night $(2400$ hours) on 6-7 September 1994.

Five juvenile kokanee were added to each of the three nutrient addition treatment limnocorrals (NF) and three of the fish-only control limnocorrals (F) on 12 August 1994. This density of 0.014 fish/L is slightly higher than densities of planktivores measured by means of combined hydroacoustic and trawling estimates of population abundance for localized habitats of juvenile salmon (Steinhart et al. 1993; Teuscher and Taki 1994; Beauchamp et al., in press). Fish were anesthetized with tricaine methanesulfonate (MS-222), measured for total length (TL, nearest millimeter), weighed (nearest $0.01 \mathrm{~g}$ ), and given a unique fin clip in order to measure individual growth rates. The mean size $( \pm \mathrm{SE})$ of stocked fish was $0.34 \mathrm{~g} \pm$ 0.07 and $39 \mathrm{~mm} \pm 4$. Fish were allowed to recover for several hours before addition to each limnocorral. At the end of the experiment, $87 \%$ (26 of 30 ) of the initially stocked kokanee were removed from the experiment by using dry ice asphyxiation ( $\sim 45 \mathrm{~kg} /$ limnocorral). The fish were then measured and weighed. Differences in fish growth ( $g$ gained. $\mathrm{g}^{-1}$ initial weight $\cdot \mathrm{d}^{-1}$ ) were analyzed for statistical significance with a one-way ANOVA.

Repeated-measure ANOVAs, accounting for time and initial differences among treatments, were used to analyze most limnological variables for statistical significance (Wilkinson 1990). The experiment was statistically analyzed as the two parts described above (part 1 = nutrient additions, part 2 = nutrient and fish additions). Thus, there were two treatments for part 1 with three replicates 


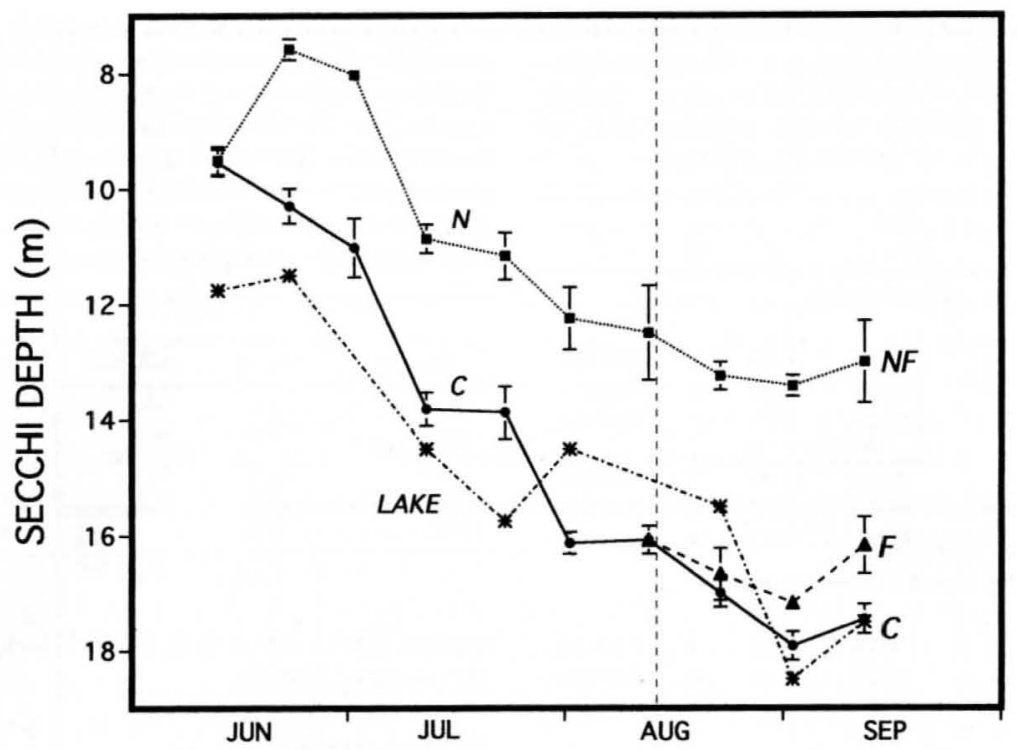

FIGURE 1.-Temporal changes in mean ( \pm SE) Secchi depth in the three enclosure treatments and in Redfish Lake, Idaho. For part 1 of the experiment (pre-fish) there were only two treatments: controls (C, solid circles) and nutrient additions ( $N$, solid squares). For part 2 of the experiment, after fish were added, there were three treatments: controls (C), fish (F, solid triangle), and nutrients and fish (NF, solid squares). The vertical dashed line indicates the start of part 2, the day the fish were added (13 August 1994). Lake values (starred points and dashed lines) are included for comparison.

for the nutrient additions (NF) and six replicates for the control treatments (C and F). For part 2, there were three replicates of the $\mathrm{C}$ treatment, three replicates of the $\mathrm{F}$ treatment, and three replicates of the NF treatment. Because of the low power of our experimental design, we chose to use an $\alpha$ of 0.10 to evaluate the effects of the nutrient additions.

\section{Results}

\section{Temperature and Oxygen}

Temperature and oxygen conditions in each treatment were similar and showed the same pattern observed in the lake for the duration of the experiment (Budy et al. 1994). Dissolved oxygen ranged from 6 to $9 \mathrm{mg} / \mathrm{L}$ during the experiment. Epilimnetic temperatures ranged from 11 to $15^{\circ} \mathrm{C}$, metalimnetic (11-12 $\mathrm{m}$ ) temperatures ranged from 6.5 to $12^{\circ} \mathrm{C}$, and temperatures at the bottom of the limnocorral remained below $7.5^{\circ} \mathrm{C}$.

\section{Water Transparency}

On any date, Secchi depth transparencies were 2-4 $\mathrm{m}$ shallower in fertilized limnocorrals (NF) than in the control limnocorrals ( $\mathrm{F}$ and $\mathrm{C}$; Figure 1). All limnocorrals showed a general pattern of increasing water clarity through the summer that was similar to that observed in the lake. Before the fish were added, there was no significant difference in Secchi depth among treatments, but there were significant time and treatment $\times$ time effects (Table 1). After fish were added, time and treatment $\times$ time effects disappeared, but a significant treatment effect occurred. These results indicated that significant differences in water transparency between fertilized and unfertilized treatments arose through time and were maintained throughout part 2 of the experiment (Table 1). Secchi depth transparencies in control treatments were similar to those observed outside of limnocorrals in the open water of the lake (Figure 1).

\section{Nutrient Analyses}

Nutrient additions to the limnocorrals had relatively little effect on phosphorus levels or N:P ratios (Table 2). Total nutrient concentrations (TP and TKN) appeared slightly higher in nutrient addition treatments, but differences were not statistically significant (TP: $F=2.27 ; \mathrm{df}=1,16 ; P=$ 0.15 ; TKN: $F=3.31 ; \mathrm{df}=1,8 ; P=0.11$ ). Soluble nutrient concentrations were also similar in all treatments (SRP: $F=0.03$; df $=1,6 ; P=0.88$; $\left.\mathrm{NO}_{2}+\mathrm{NO}_{3}: F=1.48 ; \mathrm{df}=1,6 ; P=0.27\right)$. Soluble nutrient concentrations remained low throughout 
TABLE 1.-Analysis of variance (ANOVA) by treatment for the limnological variables analyzed with repeated measures for the two parts of the experiment (part 1 = prefish; part $2=$ postfish). Statistics for other variables analyzed with regular ANOVAs are provided in the text.

\begin{tabular}{lcccc}
\hline $\begin{array}{l}\text { Part and source } \\
\text { of variation }\end{array}$ & $\begin{array}{c}\text { Mean } \\
\text { square }\end{array}$ & $F$ & df & $P$ \\
\hline & Secchi depth & & & \\
Part 1 & 18.9 & 0.19 & 1 & 0.67584 \\
$\quad$ Treatment & 174.19 & 2.01 & 6 & 0.08526 \\
$\quad$ Time & 259.13 & 2.99 & 6 & 0.01584 \\
$\quad$ Treatment $\times$ time & & & & \\
Part 2 & 42.66 & 59.99 & 2 & 0.00036 \\
$\quad$ Treatment & 1.01 & 1.55 & 2 & 0.25843 \\
$\quad$ Time & 0.14 & 0.22 & 4 & 0.92146 \\
$\quad$ Treatment $\times$ time & &
\end{tabular}

Epilimnetic chlorophyll $a$

Part 1

$\begin{array}{lrrrr}\text { Treatment } & 6.16 & 56.53 & 1 & 0.00014 \\ \text { Time } & 2.93 & 32.15 & 6 & 0.00000 \\ \text { Treatment } \times \text { time } & 1.02 & 11.17 & 6 & 0.00000 \\ \text { Part 2 } & & & & \\ \text { Treatment } & 0.66 & 2.54 & 2 & 0.15852 \\ \text { Time } & 18.41 & 24.82 & 2 & 0.00005 \\ \text { Treatment } \times \text { time } & 0.17 & 0.22 & 4 & 0.91953\end{array}$

Metalimnetic chlorophyll $a$

$\begin{array}{lrrrr}\text { Part 1 } & & & & \\ \quad \text { Treatment } & 24.49 & 20.88 & 1 & 0.00258 \\ \quad \text { Time } & 12.39 & 28.46 & 6 & 0.00000 \\ \quad \text { Treatment } \times \text { time } & 3.42 & 7.84 & 6 & 0.00001 \\ \text { Part 2 } & & & & \\ \quad \text { Treatment } & 3.12 & 5.80 & 2 & 0.03958 \\ \quad \text { Time } & 0.59 & 0.48 & 2 & 0.62806 \\ \quad \text { Treatment } \times \text { time } & 0.55 & 0.45 & 4 & 0.76785\end{array}$

Overall chlorophyll $a$

$\begin{array}{lrrrr}\text { Part 1 } & & & & \\ \quad \text { Treatment } & 42.67 & 56.72 & 1 & 0.0001 \\ \quad \text { Time } & 4.44 & 3.10 & 2 & 0.1029 \\ \quad \text { Treatment } \times \text { time } & 3.26 & 2.28 & 2 & 0.1619 \\ \text { Part 2 } & & & & \\ \quad \text { rreatment } & 1.20 & 25.23 & 2 & 0.0012 \\ \quad \text { Time } & 0.16 & 1.16 & 2 & 0.3361 \\ \text { Treatment } \times \text { time } & 0.16 & 1.22 & 4 & 0.3569\end{array}$

Zooplankton biomass

Part 1

\begin{tabular}{lrrrr} 
Treatment & $3,364.64$ & 4.43 & 1 & 0.07325 \\
Time & $3,038.16$ & 14.39 & 6 & 0.00000 \\
$\quad$ Treatment $\times$ time & 826.90 & 3.92 & 6 & 0.00339 \\
Part 2 & & & & \\
$\quad$ Treatment & $7,145.24$ & 4.91 & 2 & 0.05452 \\
Time & 804.47 & 2.89 & 2 & 0.09452 \\
Treatment $\times$ time & 479.94 & 1.72 & 4 & 0.20921 \\
\hline
\end{tabular}

the experiment, indicating that nutrient uptake by phytoplankton was rapid in all treatments. The SRP concentrations remained near our analytical detection limits $(1 \mu \mathrm{g} / \mathrm{L})$. The ratio of total nitrogen to total phosphorus differed little between treatments. Nutrient concentrations in control treatments were generally similar to nutrient concentrations observed in lake samples (summer lake
TABLE 2.-Treatment means and SEs of nutrient concentrations in integrated water column samples $(17-0 \mathrm{~m})$ for the duration of the experiment in the nutrient (NF) and control $(\mathrm{C}+\mathrm{F})$ treatments for measured nutrients and for the N:P ratio. All values are in $\mu \mathrm{g} / \mathrm{L} ; \mathrm{TP}=$ total phosphorus, $\mathrm{SRP}=$ soluble reactive phosphorus, $\mathrm{TKN}=$ total Kjeldahl nitrogen, $\mathrm{NO}_{3}=$ nitrate, $\mathrm{NO}_{2}=$ nitrite, $\mathrm{N}: \mathrm{P}=$ total nitrogen to total phosphorus ratio.

\begin{tabular}{lrlrcc}
\hline & \multicolumn{2}{c}{$\mathrm{C}+\mathrm{F}$} & & \multicolumn{2}{c}{$\mathrm{NF}$} \\
\cline { 2 - 3 } \cline { 5 - 6 } Variable & Mean & $\mathrm{SE}$ & & Mean & $\mathrm{SE}$ \\
\hline $\mathrm{TP}$ & 10.3 & 0.7 & & 12.08 & 0.8 \\
$\mathrm{SRP}$ & 2.3 & 0.3 & & 2.4 & 0.6 \\
$\mathrm{TKN}$ & 52.5 & 7.5 & & 84.4 & 16.0 \\
$\mathrm{NO}_{3}+\mathrm{NO}_{2}$ & 1.1 & 0.4 & & 5.4 & 3.05 \\
$\mathrm{~N}: \mathrm{P}$ & 5.8 & & & 5.4 & \\
\hline
\end{tabular}

means, $\mu \mathrm{g} / \mathrm{L}: \mathrm{TP}=8.9, \mathrm{SRP}=0.5, \mathrm{TKN}=66.4$, $\mathrm{NO}_{2}+\mathrm{NO}_{3}=0.8$ ).

\section{Phytoplankton}

Nutrient additions markedly increased chlorophyll- $a$ levels in the limnocorrals (Figure 2). Epilimnetic chlorophyll in the nutrient addition limnocorrals (NF) was generally $70-100 \%$ greater than in control treatments, with the exception of a peak in chlorophyll near the start of the experiment (Figure 2a). Nutrient additions significantly increased epilimnetic chlorophyll- $a$ concentrations before fish were added to the experiment (Table 1). After fish were added, there was a significant time effect but no significant treatment or treatment $\times$ time effect on epilimnetic chlorophyll, indicating that the addition of fish did not influence epilimnetic algal abundance. Epilimnetic chlorophyll $a$ in control limnocorrals paralleled values observed in the epilimnion of the lake (Figure 2a). Nutrient additions increased metalimnetic chlorophyll- $a$ levels $150-300 \%$ over levels observed in control limnocorrals (Figure 2b). Metalimnetic chlorophyll- $a$ concentrations showed the same high peak near the start of the experiment in both nutrient addition and control treatments as observed in the epilimnion. The difference in metalimnetic chlorophyll concentrations among treatments was statistically significant before fish were added (Table 1).

Chlorophyll- $a$ concentrations measured from integrated samples from the whole water column $(17-0 \mathrm{~m})$ showed the same general pattern of nutrient stimulation observed in the epilimnetic and metalimnetic chlorophyll measurements (Figure 2c). Nutrient additions increased water column chlorophyll $a$ 100-350\% over control treatments. This increase in chlorophyll $a$ in whole water col- 


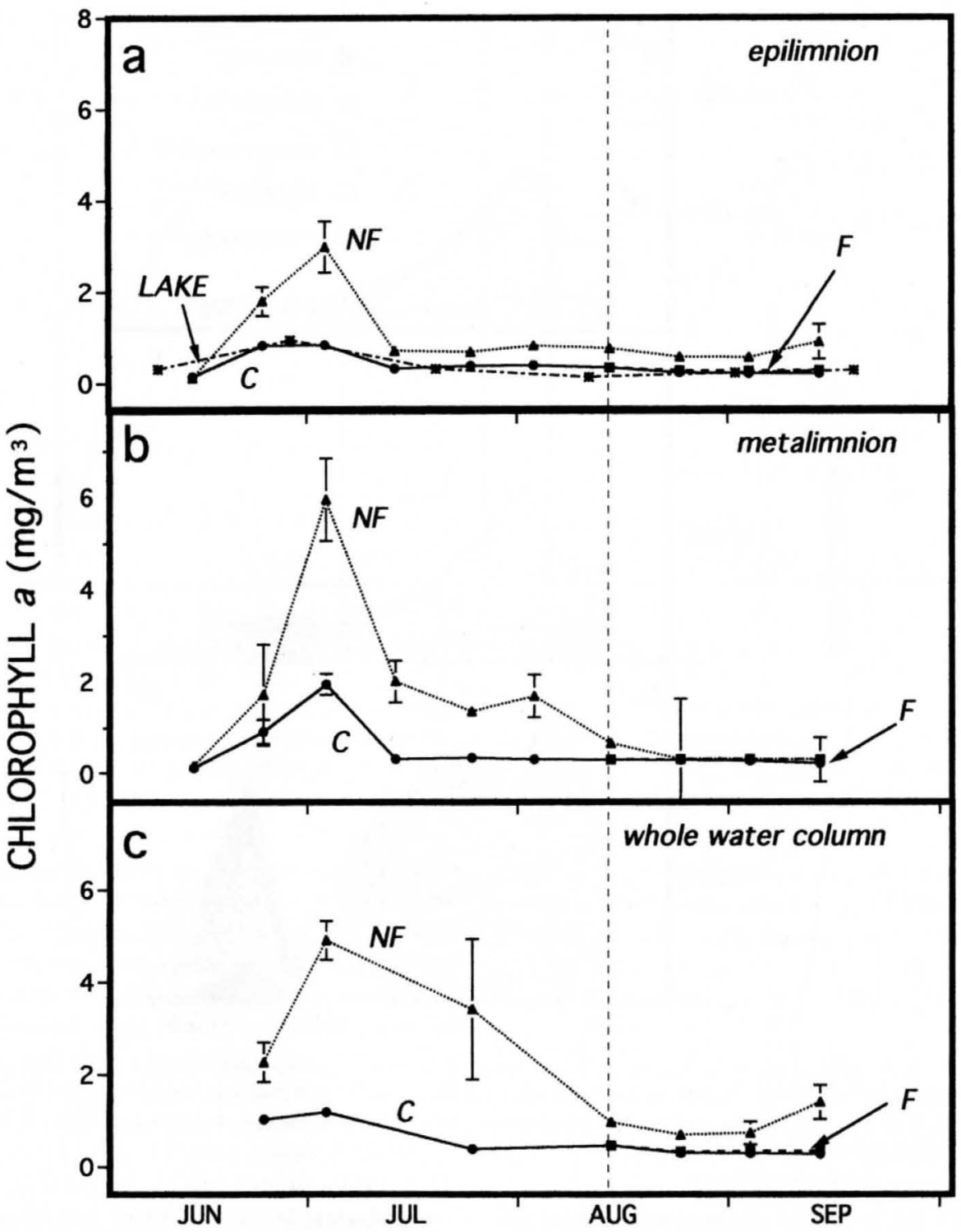

FIGURE 2.-Mean ( \pm SE) chlorophyll- $a$ concentrations for the C, NF, and F limnocorrals: (a) epilimnion values (6-0 m) for limnocorrals and for Redfish Lake (starred point); (b) metalimnion (11-12 m) values for the limnocorrals; and $(\mathbf{c})$ whole water column tow $(17-0 \mathrm{~m})$ values for the limnocorrals. Symbols and vertical dashed line are defined as in Figure 1.

umn samples was statistically significant for part 1 and part 2 of the experiment; there was no significant treatment $\times$ time effect for part 1 and no significant time or treatment $\times$ time effects for part 2 (Table 1). Depth profiles of chlorophyll $a(0.5$, $6,11-12$, and $17 \mathrm{~m}$ ) taken on 2 July, 1 August, and 1 September 1994 indicated greatest chlorophyll- $a$ concentrations near the metalimnion of the nutrient addition treatments. On 2 July and $1 \mathrm{Au}-$ gust, 1994, chlorophyll- $a$ concentration was greatest in the metalimnion of nutrient addition treatments and greatest at the bottom of control treatments (17 m). By 1 September, however, the chlorophyll- $a$ profile revealed little difference in chlorophyll- $a$ concentration with depth.

Nutrient additions appeared to enhance phytoplankton biovolume in whole water column samples $(17-0 \mathrm{~m})$ on seven of eight dates analyzed 


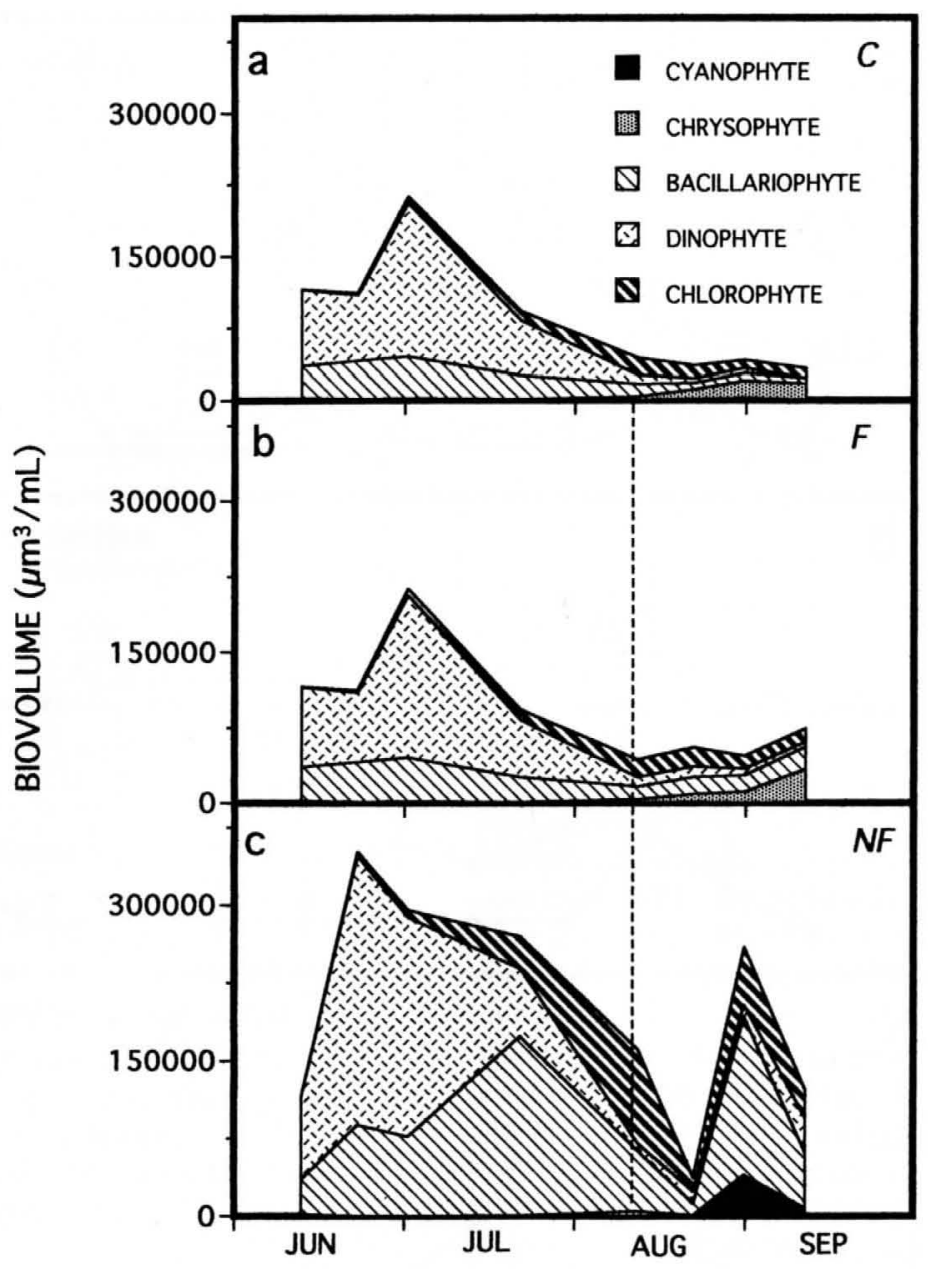

FIGURE 3.-Seasonal changes in the mean biovolume of identified phytoplankton taxa from integrated water column samples $(17-0 \mathrm{~m})$ for the three limnocorral treatments: (a) $\mathrm{C}=$ controls; $(\mathbf{b}) \mathrm{F}=$ fish; and $(\mathbf{c}) \mathrm{NF}=$ nutrient and fish. The top line in each graph corresponds to total phytoplankton biovolume. Vertical dashed line indicates date that fish were added.

(Figure 3). Early in the experiment, nutrient additions stimulated the already dominant Dinophyta and Bacillariophyta twofold to threefold above control treatments. Nutrient additions also appeared to stimulate Chlorophyta biovolume as the experiment progressed. By late August, a small peak in cyanobacteria biovolume was observed in nutrient addition treatments (NF), while chrysophytes appeared in both unfertilized treatments (C and F). Both total phytoplankton biovolume and taxonomic composition of the phytoplankton were similar among control treatments and phytoplankton sampled in the lake.

Depth profiles of phytoplankton biovolume on three dates (2 July, 1 August, and 31 August 1994) showed higher (10-350\%) biovolume at all depths in the nutrient addition treatments than in the control treatments. General trends of increasing depth of maximum phytoplankton biovolume and an overall decline in biovolume at all depths through time were observed in all treatments. The greatest phytoplankton biovolume was observed at $17 \mathrm{~m}$ in control treatments $(\mathrm{C}$ and $\mathrm{F})$ and at $11 \mathrm{~m}$ in nutrient addition treatments (NF) on 2 July 1994. This pattern switched on 1 August 1994 when biovolume was considerably reduced at all depths in the controls, and the greatest biovolume was observed at $17 \mathrm{~m}$ in nutrient addition treatments.

Periphyton was not abundant in any of the limnocorrals until August and remained negligible in control ( $\mathrm{C}$ and $\mathrm{F}$ ) treatments throughout the experiment. A comparison of the total amount of 


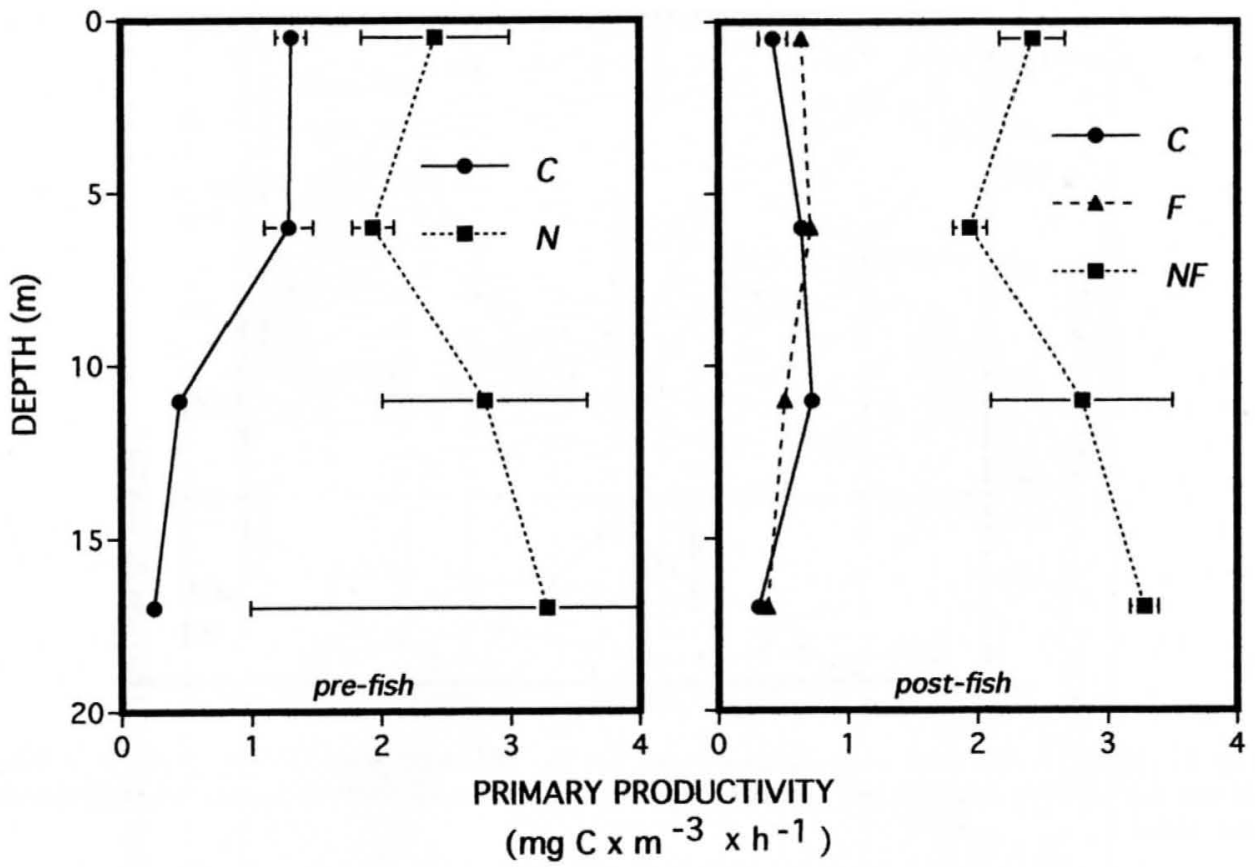

FIGURE 4.- Primary productivity in limnocorrals before fish were added (pre-fish, 1 August 1994) and after fish were added (post-fish, 31 August 1994) at four depths $(0.5,6,12,17 \mathrm{~m})$. The values shown represent the mean ( $\pm \mathrm{SE})$ of the three treatments $(\mathrm{C}=$ controls, $\mathrm{F}=$ fish, $\mathrm{NF}=$ nutrient and fish $)$.

chlorophyll $a$ in each limnocorral from periphyton versus that from phytoplankton shows a switch from higher phytoplankton chlorophyll $a$ (phytoplankton $=1.0 \mu \mathrm{g} / \mathrm{L}$; periphyton $=0.1 \mu \mathrm{g} / \mathrm{L}$ ) early in the experiment to dramatically higher periphyton chlorophyll $a$ in nutrient addition treatments by late August (phytoplankton $=<1 \mu \mathrm{g} / \mathrm{L}$; periphyton $=9 \mu \mathrm{g} / \mathrm{L})$. Nutrient additions stimulated periphyton at all four depths sampled, and the metalimnetic (11 and $12 \mathrm{~m}$ ) samples showed the greatest periphyton accumulation. The least amount of periphyton growth was observed in epilimnetic samples $(1$ and $6 \mathrm{~m})$ in all treatments.

Primary production $\left(\mathrm{mg} \mathrm{C} \cdot \mathrm{m}^{-3} \cdot \mathrm{h}^{-1}\right)$ was greater in the nutrient addition limnocorrals than in control limnocorrals both before and after fish were added and at all depths sampled (Figure 4). Before fish were added, primary production in the control treatments was higher in the epilimnion $(0.5 \mathrm{~m}$ and $6 \mathrm{~m})$ than the metalimnion (11-12 m) and hypolimnion $(17 \mathrm{~m})$. In the nutrient addition treatments, rates of primary production were greatest in the hypolimnion, followed by the metalimnion. After fish were added, rates of primary production remained higher in the nutrient addition limnocorrals than in the fish (F) or control (C) treatments. Depth-integrated mean primary production in nu- trient addition treatments was statistically higher than in control treatments for part 1 (mean square $=6.37,0.32 ; F=20.20 ; \mathrm{df}=1,6 ; P=0.004$ ) and part 2 (mean square $=1.73,0.26 ; F=6.59$; df $=2,9 ; P=0.017)$ of the experiment.

\section{Zooplankton}

Zooplankton total biomass clearly responded to nutrient additions, increasing overall during the experiment (Figure 5). Total zooplankton biomass was greater in nutrient addition treatments than in control treatments from 12 July 1994 to the end of the experiment. Zooplankton biomass was very low at the start of the experiment in both treatments $(<1 \mu \mathrm{g} / \mathrm{L})$ but then increased $200-300 \%$ in control treatments (C and F) and $900 \%$ in nutrient addition treatments (NF). Zooplankton biomass showed significant treatment, time, and treatment $\times$ time effects for part 1 of the experiment (Table 1). The increase in zooplankton in nutrient addition limnocorrals over control limnocorrals continued after fish were added, as indicated by significant treatment and time effects. After the fish were added, total zooplankton biomass slightly increased in the $\mathrm{F}$ treatment compared to the $\mathrm{C}$ treatments. Total zooplankton biomass in control limnocorrals was generally $5-10 \mu \mathrm{g} / \mathrm{L}$ higher than in 


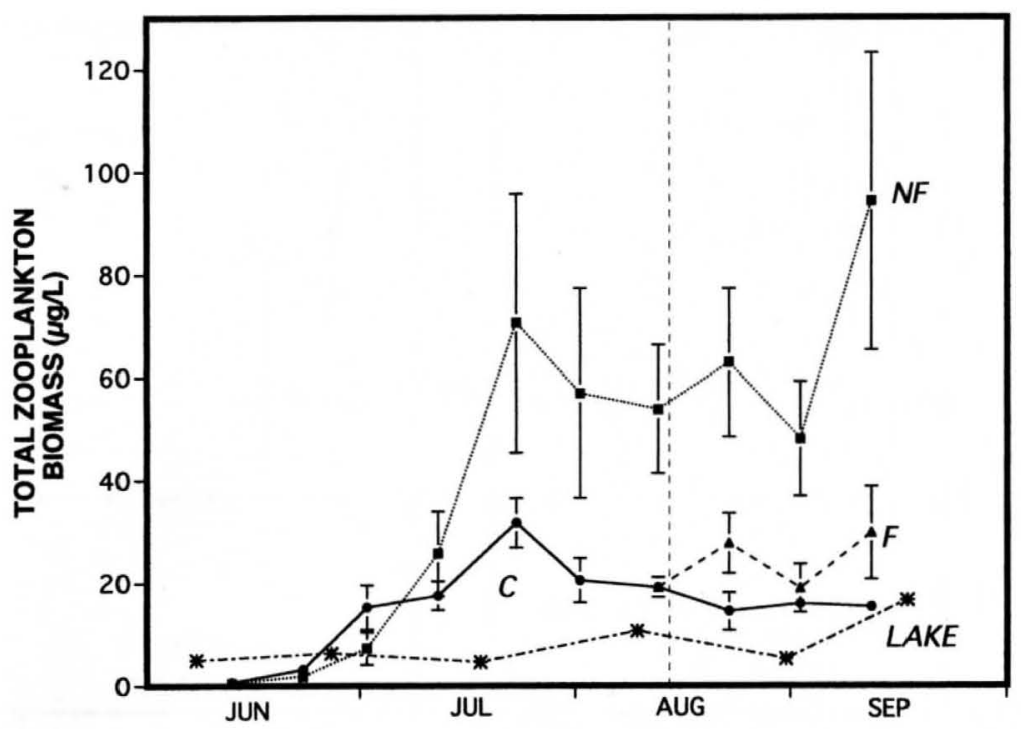

FIGURE 5.-Mean $( \pm \mathrm{SE})$ total zooplankton biomass for the three treatments $(\mathrm{C}=$ controls, $\mathrm{F}=\mathrm{fish}, \mathrm{NF}=$ nutrient and fish) and for Redfish Lake (starred points and dashed lines). Vertical dashed line indicates date that fish were added.

the lake for the duration of the experiment (Figure $5)$.

Zooplankton taxonomic composition in the limnocorrals was dominated by cladocerans, and cyclopoid copepods usually contributed less than 5\% of the total crustacean biomass. Cladoceran zooplankton species composition was dominated by Bosmina and Holopedium in all treatments early in the experiment (Figure 6). On 22 July 1994, the species composition shifted as the proportion of Daphnia began to increase and the proportion of both Holopedium and Bosmina began to decline. Control treatments showed a small peak in Holopedium on 22 August 1994 that was not observed in either the F or NF treatments. Daphnia appeared slightly more abundant in the NF treatment than in either the $\mathrm{C}$ or $\mathrm{F}$ treatments during part 2 of the experiment. Trends in zooplankton taxonomic composition in all treatments closely paralleled those observed in the lake (Budy et al. 1994).

Diel vertical migration of crustacean zooplankton was minimal in all limnocorrals. During both day and night, the highest biomass of zooplankton $(\mu \mathrm{g} / \mathrm{L})$ was observed in the epilimnion $(6-0 \mathrm{~m})$ in all three treatments (35-63\% of the total biomass). At night, zooplankton biomass was lowest in the bottom stratum of each limnocorral, but during the day, zooplankton biomass was similar in metalimnetic and hypolimnetic strata.

\section{Fish Growth}

Final mean weight of fish in the nutrient addition treatments was greater than in the control treatments (1.92 $\mathrm{g}$ and $1.78 \mathrm{~g}$, respectively). Mean growth rate $( \pm S E)$ was $0.064( \pm 0.003)$ in the nutrient addition treatment and $0.057( \pm 0.005)$ in the fish treatment, a difference of $12 \%$ (Figure 7). An ANOVA indicated that this difference in fish growth was not significant (mean square $=00,00$; $F=1.1 ; \mathrm{df}=1,4 ; P=0.36$ ). Although the variance for the means in this analysis was small, the power was low (42\%) due to the low number of replicates per treatment $(N=3)$ (Peterman 1990).

\section{Discussion}

The limnocorral experiment was conducted to assess the likelihood that a whole-lake fertilization would enhance the growth and production of endangered juvenile sockeye salmon stocked into Redfish Lake in 1995. Previous lake fertilization studies revealed that phytoplankton production was almost always stimulated by nutrient additions (Stockner 1987; Shortreed and Stockner 1990; Kyle et al. 1997) but that increases in zooplankton and fish production were more uncertain (Stockner 1981; Koenings and Burkett 1987). Results from our limnocorral experiment showed that addition of inorganic nutrients increased primary production, chlorophyll- $a$ concentration, phytoplankton 


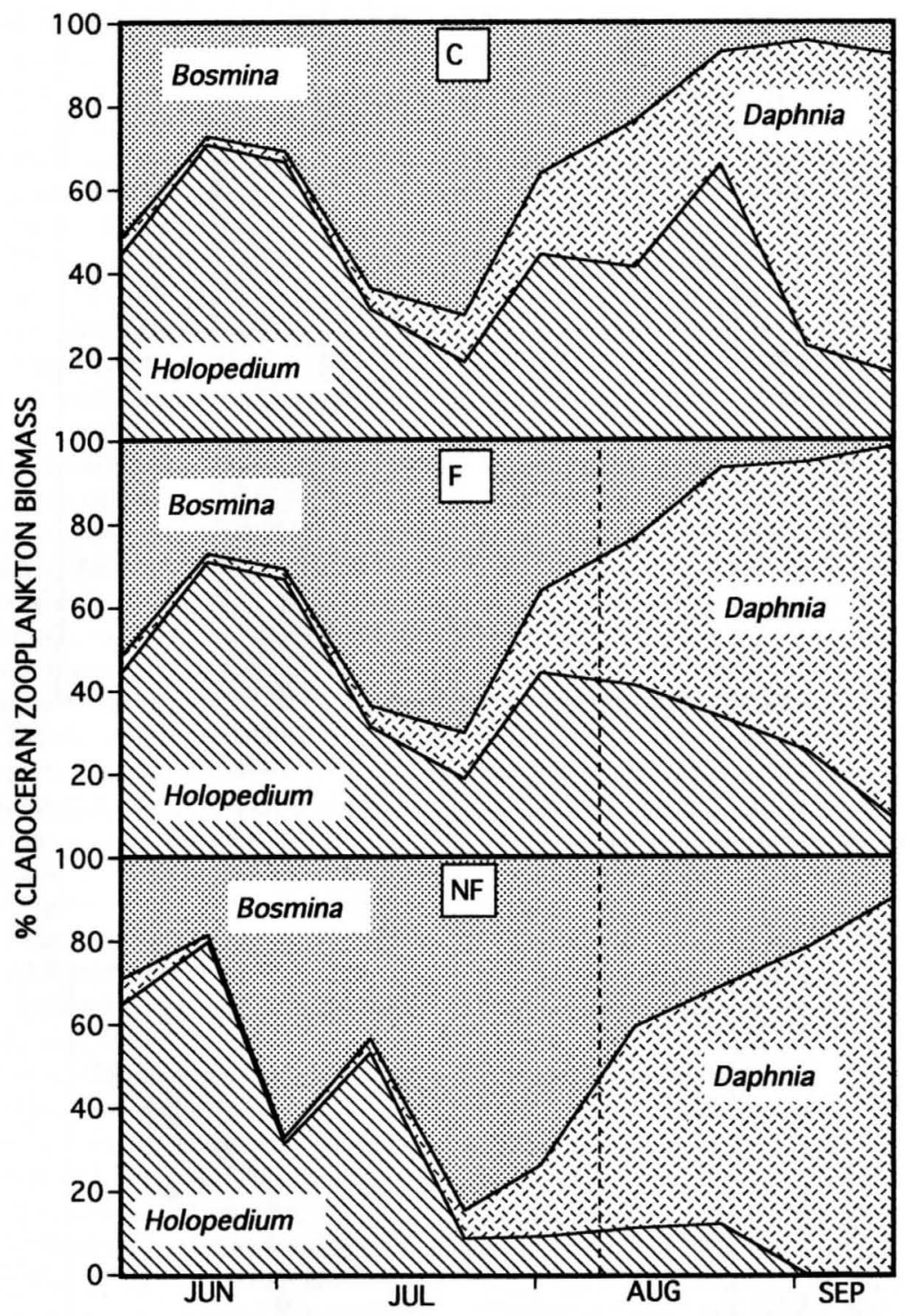

FIGURE 6.-Cladoceran zooplankton taxanomic composition in the three treatments during the experiment. The three replicate limnocorrals were averaged for each treatment $(\mathrm{C}=$ controls, $\mathrm{F}=\mathrm{fish}$, and $\mathrm{NF}=$ nutrient and fish), and data are shown as percent of total biomass of cladoceran zooplankton. Vertical dashed line indicates date that fish were added.

biomass, and zooplankton biomass. Adding nutrients for a period of time before the addition of fish appeared to stimulate trophic transfer within the food web such that zooplankton rapidly responded to increased phytoplankton food. This increase in zooplankton was available as forage for these juvenile fish.

We view the increase in zooplankton biomass as particularly important in that other analyses we have conducted indicated that zooplankton food resources strongly affect the growth of juvenile salmon. In three Sawtooth Valley lakes (19921995), growth of juvenile kokanee increased with increasing food resources, and in net-pen cage experiments in two of these lakes (1993 and 1995), age-0 kokanee grew faster in the lake that had higher food availability (Figure 8; Budy 1996). The low growth rate of fish in an oligotrophic lake, such as Redfish Lake, coupled with the small number of replicates feasible in our limnocorral ex- 


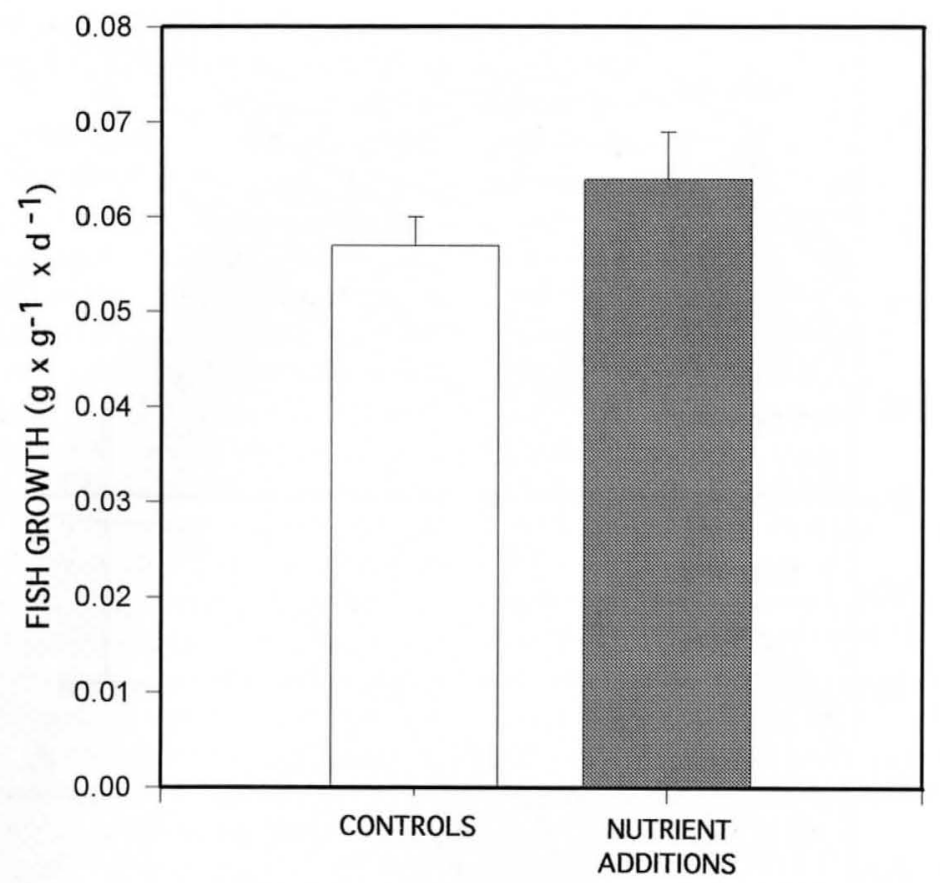

FIGURE 7.-Mean (+ SE) daily growth rate (weight gained, g/initial weigh, g) for kokanees in nutrient addition (filled bar) and control treatments (open bar).

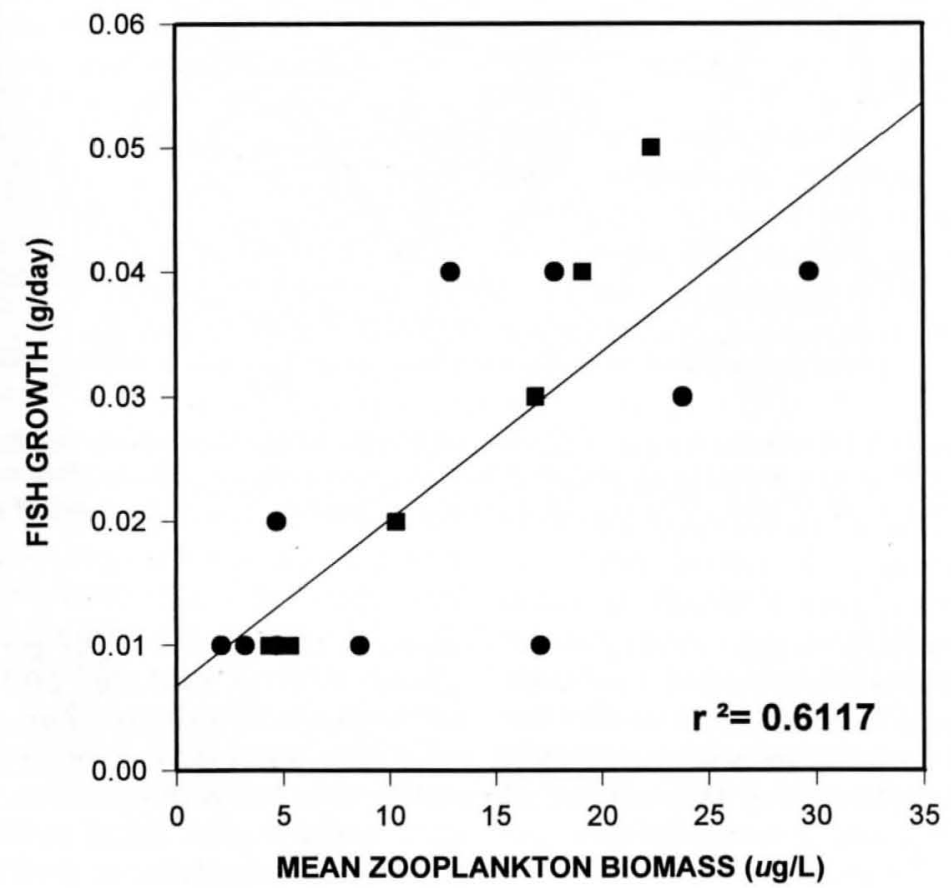

FIGURE 8.-Fish growth (g/d) observed in age-0 kokanee caught in trawls during September (1992-1995) in three Sawtooth Valley lakes (circles) and from juvenile kokanee grown in net-pens in Redfish and Stanley lakes in 1993 and 1995 (squares). 
periment, reduced statistical power $(42 \%)$. Nevertheless, the fish in nutrient addition treatments were growing at a faster growth rate than fish grown in control treatments. We conclude that fertilization of Redfish Lake would probably enhance food resources and growth of juvenile sockeye salmon, particularly if the fertilization was initiated 4-6 weeks before fish were stocked. Currently, endangered juvenile sockeye salmon from the broodstock program are stocked into the nursery lakes in August and September (Idaho Department of Fish and Game, personal communication).

Addition of nutrients to the metalimnion rather than the epilimnion of limnocorrals indicated that enhancement of trophic transfer could occur without dramatically reducing water clarity. In a previous limnocorral experiment in Redfish Lake, additions of nutrients to the epilimnion of limnocorrals reduced mean Secchi transparencies by $75 \%$ compared with values in control limnocorrals (Budy et al. 1994). In our present study, mean Secchi transparency in metalimnetic fertilization treatments averaged about $85 \%$ of control and lake values. Metalimnetic fertilization resulted in water transparencies always exceeding $7 \mathrm{~m}$, a value associated with high water quality (Goldman and Horne 1983). Similarly, Gross et al. (1994) reported comparable differences in water transparency between epilimnetic and metalimnetic fertilization experiments.

Although nutrients in our experiments were added to the metalimnion of the limnocorrals, phytoplankton biomass was increased in both epilimnetic and metalimnetic strata. This observation suggests that the added nutrients were transferred to the top $6 \mathrm{~m}$ of the limnocorral by water currents, by the movement and excretion of zooplankton and fish, and by our use of zooplankton nets and other sampling equipment. Nutrient additions stimulated the growth of sizes and species of phytoplankton that are grazeable by most cladoceran zooplankton (Porter 1973; Lampert 1978; Sommer 1988). The species composition of phytoplankton was similar among treatments and in the lake, indicating that the high N:P ratio and modest degree of nutrient addition kept nitrogen-fixing cyanobacteria from becoming dominant, as has been reported in other fertilization studies (Schindler 1977; Stockner and Shortreed 1988).

A comparison of chlorophyll $a$ in the phytoplankton versus the periphyton indicated that a substantial amount of nutrients were utilized by periphyton communities growing on the sides of the limnocorrals in the latter half of the experiment. This accumulation of high levels of periphyton in the second part of the experiment was probably due in part to the lack of periphyton grazers present in our pelagic limnocorrals. The inclusion and increased production of herbivorous zooplankton probably contributed to the decline of phytoplankton in the water column after mid-July. These differences in grazing regimes allowed for more efficient trophic transfer in the pelagic food web than in the periphyton-based community. By the end of the experiment, about $90 \%$ of the chlorophyll in the limnocorrals was on the walls. While the stimulation of periphyton is an alternative pathway of energy transfer that may influence whole-lake fertilization (Goldman 1981), the exclusion of periphyton grazers and the high surface area:volume ratio in the limnocorrals compared with the lake suggest that periphyton growth would be much less pronounced during a wholelake fertilization. Although some nutrients were lost to periphyton in the limnocorrals, primary production of phytoplankton was significantly stimulated by nutrient additions throughout the experiment and provided sufficient food resources to maintain the increased biomass of pelagic zooplankton.

Despite the considerable increase in total zooplankton biomass in nutrient addition treatments, zooplankton taxonomic composition differed little among treatments. The small difference in zooplankton composition in nutrient addition treatments compared with controls was due to an increase in Daphnia, a zooplankton species preferred by juvenile salmonids (Lazzarro 1987; Luecke and Brandt 1993). Comparisons of zooplankton biomass in control treatments with that observed in the natural lake environment during similar time periods revealed that ambient densities of zooplankton in the lake were considerably lower than in control limnocorrals. Thus the refuge from fish predation for the first half of the experiment probably contributed to the greater zooplankton biomass observed in limnocorrals over ambient lake densities (Stich and Lampert 1981; Iwasa 1982; Gliwicz 1986; Stirling et al. 1990; Schmidt et al. 1994). However, the increased zooplankton biomass was maintained in nutrient addition treatments after the fish were added.

The stocking of several hundred thousand juvenile sockeye salmon into Redfish Lake over the next 3 years from the broodstock program may cause negative density-dependent effects on fish growth (Rieman and Meyers 1992). The oligotro- 
phic nature and current abundance of kokanee in Redfish Lake suggest that lake carrying capacity may be exceeded by the stocking program (Budy et al. 1995; Luecke et al. 1996). The increased zooplankton biomass and fish growth rate in fertilized limnocorrals over control limnocorrals, in addition to the high growth rates demonstrated by all fish in the experiment, suggest that fertilization would increase the carrying capacity of Redfish Lake. Our experiment, in combination with limnological sampling and simulation modeling, suggests that a modest program of lake fertilization, in combination with a reduction of landlocked kokanee, could overcome these negative density-dependent effects expected to accompany the stocking of endangered broodstock individuals (Luecke et al. 1996).

These results suggest that increased growth under lake fertilization may improve the ability of these fish to thrive and ultimately return from the marine environment. If mortality is strongly size dependent, larger juvenile sockeye salmon entering the winter would likely be better able to avoid piscivorous northern squawfish Ptychocheilus oregonensis and bull trout Salvelinus confluentus in Redfish Lake (Luecke et al. 1990; Marschall and Crowder 1995). An increase in growth rate will also probably increase the survival of these juvenile fish on their perilous migration through the Snake and Columbia rivers and reservoirs (Rieman et al. 1991; Vigg et al. 1991; Peterson et al. 1993). Poe et al. (1991) demonstrated that juvenile salmonids made up $67 \%$ of northern squawfish diets in John Day Reservoir on the Columbia River, representing a mean annual loss that Rieman et al. (1991) estimated at 2.7 million juvenile salmonids per year. Further, northern squawfish consistently consumed juvenile salmonids from smaller sizegroups, indicating that mortality was size-specific. These suppositions provide further support for the use of lake fertilization as a tool to enhance production of this endangered stock.

\section{Acknowledgments}

We thank Jim Ruzycki, Odette Brandt, Nick Bouwes, and Geoff Steinhart for field assistance; Odette Brandt for enumerating zooplankton; and Jim Ruzycki for nutrient analyses. Thorsten Blenckner identified and enumerated phytoplankton. Dave Teuscher and Bob Griswold provided scuba assistance. Roy Stein, John Stockner, and an anonymous reviewer provided helpful suggestions on previous drafts of this manuscript, and Susan Durham and Todd Crowl provided statistical advice. This research was funded through a research grant from Bonneville Power Administration subcontracted through the Shoshone-Bannock Indian tribes (contract DE-BI79-91BP22548) and by the Ecology Center at Utah State University.

\section{References}

APHA (American Public Health Association), American Water Works Association, and Pollution Control Federation. 1992. Standard methods for the examination of water and wastewater, 18th edition. APHA, Washington, D.C.

Beauchamp, D. A. In press. Hydroacoustic assessment of abundance and diel distribution of sockeye and kokanee in the Sawtooth Valley lakes, Idaho. Lake and Reservoir Management.

Bevan, D., and six coauthors. 1994. Snake River salmon recovery team: final recommendations to National Marine Fisheries Service. NMFS, Portland, Oregon.

Budy, P. 1996. Adding nutrients to enhance the growth and production of endangered sockeye salmon: trophic transfer in an oligotrophic lake. Doctoral dissertation. Utah State University, Logan.

Budy, P., C. Luecke, and W. A. Wurtsbaugh. 1994. Effects of nutrient enhancement on juvenile sockeye salmon growth. Lake and Reservoir Management 9: $140-145$.

Budy, P., C. Luecke, W. A. Wurtsbaugh, and H. Gross. 1995. Limnology of Sawtooth Valley lakes with respect to potential growth of juvenile Snake River sockeye salmon. Northwest Science 69:133-150.

Budy, P., G. Steinhart, C. Luecke, and W. A. Wurtsbaugh. 1994. Limnological investigations of Sawtooth Valley lakes, 1994. Pages 53-62 in D. Teuscher and D. Taki, editors. Snake River sockeye salmon habitat and limnological research. Prepared for U.S. Bonneville Administration, Contract DE-BI7991BP22548, Portland, Oregon.

Carpenter, S. R., and J. F. Kitchell. 1988. Consumer control of lake productivity. BioScience 38:764769.

Carpenter, S. R., and J. F. Kitchell. 1992. Trophic cascade and biomanipulation: interface of research and management-a reply to the comment by DeMelo et al. Limnology and Oceanography 37:208-213.

Carpenter, S. R., and J. F. Kitchell. 1993. The trophic cascade in lakes. Cambridge University Press, Cambridge, UK.

Crumpton, W. G. 1987. A simple and reliable method for making permanent mounts of phytoplankton for light and fluorescence microscopy. Limnology and Oceanography 21:767-783.

DeMelo, R., R. France, and D. J. McQueen. 1992. Biomanipulation: hit or myth? Limnology and Oceanography 37:192-207.

DeVries, D. R., and R. A. Stein. 1992. Complex interactions between fish and zooplankton: quantifying the role of an open-water planktivore. Canadian Journal of Fisheries and Aquatic Sciences 49:12161227.

Fretwell, S. D. 1977. The regulation of plant commu- 
nities by the food chains exploiting them. Perspectives in Biology and Medicine 20:169-185.

Gliwicz, M. Z. 1986. A lunar cycle in zooplankton. Ecology 7:883-897.

Goldman, C. R. 1981. Lake Tahoe: two decades of change in a nitrogen deficient oligotrophic lake. Internationale Vereinigung für Theoretische und Angewandte Limnologie Verhandlungen 21:45-70.

Goldman, C. R., and A. J. Horne. 1983. Limnology. McGraw-Hill, New York.

Gross, H. P., W. A. Wurtsbaugh, P. Budy, and C. Luecke. 1994. Comparison of epilimnetic and metalimnetic fertilizations on the phytoplankton and zooplankton of Pettit Lake, Idaho. Pages 78-99 in D. Teuscher and D. Taki, editors. Snake River sockeye salmon habitat and limnological research. Report to Bonneville Power Administration, Contract DE-BI7991BP22548, Portland, Oregon.

Holm-Hansen, O., and N. Rieman. 1978. Chlorophyll $a$ determination: improvements in methodology. Oikos 30:438-447.

Iwasa, Y. 1982. Vertical migration of zooplankton: a game between predator and prey. American Naturalist $120: 171-180$.

Koenings, J. P., and R. D. Burkett. 1987. An aquatic Rubic's Cube: restoration of the Karluck Lake sockeye salmon (Oncorhynchus nerka). Canadian Special Publication of Fisheries and Aquatic Sciences 96:419-434.

Koenings, J. P., J. E. Edmundson, G. B. Kyle, and J. M. Edmundson. 1987. Limnological field and laboratory manual: methods for assessing aquatic production. Alaska Department of Fish and Game, FRED (Fisheries Rehabilitation Enhancement and Development) Division, Report Series 71, Juneau.

Kyle, G. B. 1994. Assessment of trophic-level responses and coho salmon (Oncorhynchus kisutch) production following nutrient treatment (1981-1986) of Bear Lake, Alaska. Fisheries Research 20:294-261.

Kyle, G. B., J. P. Koenings, J. A. Edmundson. 1997. An overview of Alaska lake-rearing salmon enhancement strategy: nutrient enrichment and juvenile stocking. Ecological Studies 119:205-228.

Lampert, W. 1978. Release of dissolved organic carbon by grazing zooplankton. Limnology and Oceanography $23: 831-834$.

Langeland, A. 1982. Interactions between zooplankton and fish in a fertilized lake. Holarctic Ecology 5: 273-310.

Lazzarro, X. 1987. A review of planktivorous fishes: their evolution, feeding behaviors, selectivities, and impacts. Hydrobiologia 146:97-167.

LeBrasseur, R. J., and six coauthors. 1978. Enhancement of sockeye salmon (Oncorhynchus nerka) by lake fertilization in Great Central Lake: summary report. Journal of the Fisheries Research Board of Canada 35:1580-1596.

Liebold, M. A. 1989. Resource edibility and the effects of predators and productivity on the outcome of trophic interactions. American Naturalist 134:922949.

Luecke, C., and D. Brandt. 1993. Estimating the energy density of daphnid prey for use with rainbow trout bioenergetics models. Transactions of the American Fisheries Society 122:386-389.

Luecke, C., J. A. Rice, L. B. Crowder, S. F. Yeo, and F. P. Binkowski. 1990. Recruitment mechanisms of bloater in Lake Michigan: an analysis of the predatory gauntlet. Canadian Journal of Fisheries and Aquatic Sciences 47:524-532.

Luecke, C., W. A. Wurtsbaugh, P. Budy, H. P. Gross, and G. Steinhart. 1996. Simulated growth and production of endangered Snake River sockeye salmon: assessing management strategies for the nursery lakes. Fisheries 21(6):18-25.

Marschall, E. A., and L. B. Crowder. 1995. Densitydependent survival as a function of size in juvenile salmonids in streams. Canadian Journal of Fisheries and Aquatic Sciences 52:136-140.

Matson, P. A., and M. D. Hunter. 1992. Special feature. The relative contributions of top-down and bottomup forces in population and community ecology. Ecology 73:723-765.

McCauley, E. 1984. The estimation of the abundance and biomass of zooplankton in samples. Chapter 7 in J. A. Downing and F. Rigler, editors. A manual on methods of secondary productivity in freshwaters, 2nd edition. Blackwell Scientific Publishing, Oxford, UK.

McNaughton, S. J. 1977. Diversity and stability of ecological communities: a comment on the role of empiricism in ecology. American Naturalist 111:515525.

McQueen, D. J., J. R. Post, and E. L. Mills. 1986. Trophic relationships in freshwater pelagic ecosystems. Canadian Journal of Fisheries and Aquatic Sciences 43:1571-1581.

Nelson, P. R., and W. T. Edmundson. 1955. Limnological effects of fertilizing Bare Lake, Alaska. Fishery Bulletin 55(102):413-436.

Oksanen, L. 1988. Ecosystem organization: mutualism and cybernetics or plain Darwinian struggle for existence? American Naturalist 131:424-444.

Peterman, R. M. 1990. Statistical power analysis can improve fisheries research and management. Canadian Journal of Fisheries and Aquatic Sciences 47:2-15.

Peterson, B. J., and 16 coauthors. 1993. Biological responses of a tundra river to fertilization. Ecology 74:653-672.

Poe, T. P., H. C. Hansel, S. Vigg, D. P. Palmer, and L. A. Prendergast. 1991. Feeding of predaceous fishes on out-migrating juvenile salmonids in John Day Reservoir, Columbia River. Transactions of the American Fisheries Society 120:405-420.

Polis, G. A., C. A. Myers, and R. Holt. 1989. The evolution and ecology of intraguild predation: competitors that eat each other. Annual Review of Ecology and Systematics 20:297-330.

Porter, K. G. 1973. Selective grazing and differential digestion of algae by zooplankton. Nature 244:179180.

Power, M. 1992. Top-down and bottom-up forces in food 
webs: do plants have primacy? Ecology 73:733746.

Rieman, B. E., R. C. Beamsderfer, S. Vigg, and T. P. Poe. 1991. Estimated loss of juvenile salmonids to predation by northern squawfish, walleyes, and smallmouth bass in John Day Reservoir, Columbia River. Transactions of the American Fisheries Society $120: 448-458$.

Rieman, B. E., and D. L. Meyers. 1992. Influence of fish density and relative productivity on growth of kokanee in ten oligotrophic lakes and reservoirs in Idaho. Transactions of the American Fisheries Society 121:178-192.

Schindler, J. E. 1977. Evolution of phosphorus limitation in lakes: natural mechanisms compensate for deficiencies of nitrogen and carbon in eutrophied lakes. Science 195:260-374.

Schmidt, D. C., J. P. Koenings, and G. B. Kyle. 1994. Predator-induced changes in copepod vertical migration: explanations for decreased overwinter survival of sockeye salmon. Pages 188-209 in D. J. Stouder, K. L. Fresh, and R. J. Feller, editors. Theory and application in fish feeding ecology. University of South Carolina Press, Charleston.

Shortreed, K. S., and J. G. Stockner. 1990. Effect of nutrient additions on lower trophic levels of an oligotrophic lake with a seasonal deep chlorophyll maximum. Canadian Journal of Fisheries and Aquatic Sciences 47:262-273.

Sommer, U. 1988. Phytoplankton succession in microcosm experiments under simultaneous grazing pressure and resource limitation. Limnology and Oceanography 33:1037-1054.

Steinhart, G., H. P. Gross, P. Budy, C. Luecke, and W. A. Wurtsbaugh. 1993. Limnological investigations and hydroacoustic surveys of Sawtooth Valley lakes. Pages 30-61 in D. Teuscher and D. Taki, editors. Snake River sockeye salmon habitat and limnological research. Report to Bonneville Power Administration, Contract DE-B179-91BP22548, Portland, Oregon.

Stich, H., and W. Lampert. 1981. Predator evasion as an explanation of diurnal vertical migration by zooplankton. Nature 293:396-398.

Stirling, D. G., D. J. McQueen, and M. R. S. Johannes.
1990. Vertical migration in Daphnia galeata mendotae (Brooks): demographic responses to changes in planktivore abundance. Canadian Journal of Fisheries and Aquatic Sciences 47:395-400.

Stockner, J. G. 1981. Whole-lake fertilization for the enhancement of sockeye salmon (Oncorhynchus nerka) in British Columbia, Canada. Internationale Vereinigung für Theoretische und Angewandte Limnologie Verhandlungen 21:293-299.

Stockner, J. G. 1987. Lake fertilization: the enrichment cycle and lake sockeye salmon (Oncorhynchus nerka) production. Canadian Special Publication of Fisheries and Aquatic Sciences 96:198-215.

Stockner, J. G., and K. D. Hyatt. 1984. Lake fertilization: state of the art after 7 years of application. Canadian Technical Report of Fisheries and Aquatic Sciences 1324.

Stockner, J. G., and K. S. Shortreed. 1988. Response of Anabaena and Synechoccus to manipulation of nitrogen: phosphorus ratios in a lake fertilization experiment. Limnology and Oceanography 33:13481361.

Teuscher, D., and D. Taki. 1994. Population Studies. Pages 7-29 in D. Teuscher and D. Taki, editors. Snake River sockeye salmon habitat and limnological research. Report to Bonneville Power Administration, Contract DE-BI79-91BP22548, Portland, Oregon.

Vigg, S., T. P. Poe, L. A. Prendergast, and H. C. Hansel. 1991. Rates of consumption of juvenile salmonids and alternative prey fish by northern squawfish, walleyes, smallmouth bass, and channel catfish in John Day reservoir, Columbia River. Transactions of the American Fisheries Society 120:421-438.

Wetzel, R. G., and G. E. Lickens. 1991. Limnological analyses, 2nd edition. Springer-Verlag, New York.

Wilkinson, L. 1990. SYSTAT: the system for statistics. SYSTAT, Evanston, Illinois.

Winans, G. A., P. B. Aebersold, and R. S. Waples. 1996. Allozyme variability of Oncorhynchus nerka in the Pacific Northwest, with special consideration to populations of Redfish Lake, Idaho. Transactions of the American Fisheries Society 125:645-663.

Received September 1, 1996 Accepted June 10, 1997 